\title{
Where Do I Belong? Power Struggle In Miss Julie And The Hairy Ape ${ }^{1}$ Nereye Aitim? Miss Julie ve The Hairy Ape İsimli Oyunlarda Güç Mücadelesi
}

\author{
Banu Öğünç*
}

Öz

1888 yılında İsveçli oyun yazarı August Strindberg tarafından yazılan Miss Julie, cinsiyet ve sınıf açısından ana karakterler olan Jean ve Julie arasındaki güç mücadelesini ele alan natüralist bir oyundur. Oyun, aşırı hırslı olan Jean'in kendi sosyal pozisyonunu yükseltmek adına üst sınıftan olan Julie'yi etkisi altına alma çabasını anlatır. Diğer yandan 1922'de Amerikalı oyun yazarı Eugene O’Neill tarafindan yazılan Hairy Ape ekspresyonist bir oyundur. Oyun toplumda ait olduğu yeri arayan Yank'in toplumda indirgenen pozisyonunu anlatır. Çalıştığ1 şirketin sahibinin kızı tarafından 'iğrenç yaratık' diye adlandırılan Yank bir süre sonra kendine atfedilen yaratık yakıştırmasını içselleştirir. Yank aslında oyun boyunca bir sosyal gruba ait olmanın arayışı içindedir. İki farklı yüzyılda yazılmalarına ve de iki farklı kültürü ve farklı sorunları yansıtmalarına rağmen her iki oyun da işçi sınıfına ait olan erkek karakterleri ele alır. Bu bakımdan farklı akımlara ait olan bu iki oyun ortak bir temada buluşurlar. Bulundukları sosyal konum üzerine bilinçlenmelerinin ardından hem Jean hem de Yank karşılaştıkları statükocu durumlara rağmen kendi konumlarını değiştirmek adına çabalarlar. Bu çaba kadın karakterler üzerindeki aidat sorgulama ve güç kurma mücadelesini de beraberinde getirir. Bu bağlamda hiyerarşik ve maddiyatçı toplumda sosyal olarak yükselmenin yolunu ararlar. Sonuç olarak bu çalışma yüzyıldan yüzyıla ve de bir kültürden diğer kültüre devam eden güç mücadelesini erkek karakterler üzerinden Miss Julie ve Hairy Ape oyunları üzerinden incelemeyi hedeflemektedir.

Anahtar Kelimeler: Miss Julie, Hairy Ape, Sosyal sınıf, August Strindberg, Eugene O’Neill

\begin{abstract}
Written 1888 by Swedish playwright August Strindberg, Miss Julie is considered a naturalistic play that deals with power struggles between the characters Jean and Julie in terms of gender and class. As an over-reacher, Jean tries to overpower Julie in order to upgrade his social position. Hairy Ape, on the other hand, is an expressionistic play which was written by American playwright Eugene O'Neill in 1922. The play is about the degraded position of Yank who searches for his social place in the society. After being labeled as a "filthy beast" by the daughter of a steel company owner, Yank internalizes his status as an ape like creature. Throughout the play he involves in a quest as he tries to belong to a social class. Although written in two different centuries reflecting different cultures and cultural problems, both plays employ male characters who struggle to improve their position within the hierarchal and material society in spite of the status quo they face. Their struggle also includes the male characters' questioning of power over female characters. Consequently, this study aims to analyze Miss Julie and Hairy Ape in order to illustrate power struggles of the male characters that transgress one century to century and one culture to another preserving the core of the problems of the class issue in the modern society.
\end{abstract}

Keywords: Miss Julie, Hairy Ape, Social class, Power struggle, August Strindberg, Eugene O’Neill

\section{Introduction}

Written in 1888 by Swedish playwright August Strindberg, Miss Julie, the masterpiece of naturalistic drama (Lamm, 1971, p. 105), deals with power struggles between the characters Jean and Julie in terms of gender and class. Taking place in the kitchen of the Count's house, Julie's father, the play reflects the society of the late nineteenth century Sweden concentrating on the psychologies of the main characters who are the representatives of the upper class, Julie, and the working class, Jean. Throughout the play, Jean tries to overpower Julie in order to upgrade his social position. The Hairy Ape, on the other hand, is an expressionistic play which was written by American playwright Eugene O'Neill in 1922. The play tells the degraded position of Yank who searches for his social place in the society. After being labelled as a "filthy beast" by Mildred, the daughter of a steel company owner,

\footnotetext{
${ }^{1}$ Apprior version of this paper was presented in Kirikkale University Comperative Literature Symposium IV.

* Dr. Öğr. Üyesi, Aksaray Üniversitesi, Batı Dilleri ve Edebiyatları Bölümü, banuogunc@ outlook.edu.tr.
}

Öğünç, B., (2018). Where Do I Belong? Power Struggle In Miss Julie And The Hairy Ape, Gaziantep University Journal of Social Sciences, 17 (3), 857-865, Submission Date: 19-03-2018, Acceptance Date: 09-07-2018. Araştırma Makalesi. 
Yank internalizes his status as an ape like creature. This internalization leads Yank to a quest in search of the sense of belonging to a social class. In this respect, the insult by Mildred becomes an awakening call for Yank to question his social position. When compared, it can be observed that these two plays were written in two different centuries reflecting different cultures and cultural problems. However, in both plays, upon gaining consciousness on their social position, the working class characters Jean and Yank struggle to improve their position within the hierarchal and material society in spite of the status quos they face. Consequently, this study aims to analyse Miss Julie and The Hairy Ape, focusing particularly on the two male characters in these plays, in order to illustrate class struggles of Jean and Yank that transgress centuries and cultures while preserving the core of the problem of the class issue in the modern society and in the modern drama as the tragedy of the individual.

\section{The Complexity of Jean}

As a significant example of naturalism, Strindberg's play Miss Julie reflects the issues of one's heredity and social and economic environment affecting the characteristics. Nevertheless, Strindberg is also associated with expressionism as can be observed in his dream plays. Eugene O'Neill, on the other hand, who is considered to be the father of modern drama in America, employs realism, naturalism, and expressionism as influenced by Strindberg. He considers Strindberg as his inspiration in drama. Upon discussing the parallel intellectual backgrounds of Strindberg and O'Neill, Hartman specifies that "O'Neill consciously adapted Strindberg's form and subject matter to native materials" (1966, p. 216). El Sanhoury also draws the parallelism between the two playwrights: "Strindberg bares his soul in his plays and depicts himself in his heroes; O'Neill reveals many personal elements in his plays. O'Neill's ideas echo those of Strindberg, and often has O'Neill borrowed Strindberg's techniques" (1982, p. 15). While it is possible to compare different plays of these two playwrights in terms of technicality of their plays, as examples of modern drama, thematically comparison of these two names is also possible to pursue. Hartman pins such similarities down between Strindberg and O'Neill: "Born and bred as they were, these playwrights were well equipped to create the drama of the modern man alienated in insensitive and materialistic society" (1966, p. 220). This perspective also guides the thematic comparison of the characters of Jean and Yank as they struggle to establish their individual place within their class based societies in the selected plays.

While the publishers refused to publish Miss Julie and the play "had to wait eighteen years for its first professional production in Sweden" (Meyer, 1986, p. 20), it is thematically considered quite innovative for its time. Nevertheless, it can still be shocking for the modern audience as Shideler argues: "[...] [T] he play confronts issues that are as current now as they were when the play was written: class conflict, gender stereotypes and a degree of sexuality that ranges from the seductive to the sadomasochistic" (2009, p. 58). Lamm, on the other hand, on the level of characters, discusses that "[...] characterization and psychological motivation in Miss Julie show him to be a disciple of the founder of modern psychology" (1971, p. 108). Blended with Strindberg's personal experiences, the social and cultural atmosphere of his time also contribute to the play. Eventually, the play comes to the foreground as a modern tragedy of modern individuals which leads to the portrayal of Jean as a complex and vital character. In this regard, Shideler points out Strindberg's idea of "characterlessness' of his characters" explaining that "they are not limited to a narrow identity" but rather "more modern, more complex products of evolution and environment" (2009, p. 63). This perspective is based on Törnqvist's and Jacobs's idea of "role psychology" (1988, p. 85). Hence, an individual has various roles depending on the social situations. In the play, Jean, together with Julie, performs the characterlessness of his character enabling himself to be defined as a modern character unaccustomed to by the play's contemporary 
audience. This, moreover, enables a psychological study of Jean's personality as a modern individual.

In the play, Jean is mainly presented as the antagonist. Although Julie's heredity plays an important factor in her fall in the play, Jean triggers the action leading Julie to commit suicide. Julie is presented as an unstable character who suffers from the implications of her background, the aristocratic roots of her father and lower class upbringing of her mother. Jean takes advantage of Julie's confusion on her social class and gender roles. Thus, Jean undertakes the role of an antagonist as opposed to Julie as the protagonist of the play. Yet, appropriate to the complex characterization of Strindberg, Jean is not presented as an all evil character. It is possible to observe a shift in the characteristic of Jean as will be discussed in detail. However, the most significant motivation behind Jean's acts is his constant desire to accomplish an upward mobility within the class system of the society as Jean reflects in the form of a dream: "I want to get up - right to the top [...]" (Strindberg, 1958, p. 87). These general qualities of Jean are outlined by Shideler: "As Jean demonstrates his various talents, in different costumes, he is both aware of them and aware of their effect on others" $(2009, \mathrm{p}$. 66). As expressed, such awareness is derived from Jean's social desires. Suffering under the social conditions of his time, Jean intends to take advantage of these same conditions to improve his social position.

Jean explicitly states his desire to upgrade his social position to Julie in different occasions throughout the play. First, Jean impresses Julie with his French indicating that he has the capacity to learn some of the qualities of the upper class society. According to Törnqvist and Jacobs, '[...] Jean is more of an 'aristocrat' than a 'slave'. Extremely successful in the struggle for existence, he has raised himself above the people" (1988, p. 47). Templeton, on the other hand, explains these manners of Jean as "[i]n the same way that he projects his sexuality in terms of his concern for Julie's reputation, Jean also reveals his aristocratic tastes and worldliness in the disguise of servility" (1990, p. 473). While this perspective explains actions of Jean, it can also be applied to the ending of the play and Jean's attitude at the end. Following their conversation, in a shameful manner Jean shares painful past of his father's social position. He arouses pity for his degraded situation as well as reasoning his social ambitions. Through the romantic first encounter with Julie narrated in the play, Jean masks his desires for which he uses Julie, even sexually. Later Jean continues revealing his future plans: "I'm a servant now, but by next year I'll own a hotel; in ten years, I'll make enough to retire. Then I'll go to Rumania, and I'll let them pin decorations on me, and I may - mind you, I say may - finish up as a Count" (Strindberg, 1958, p. 96). Beyond Jean's desire to change his social position, this future plan of Jean also reflects truths about the social background of the period. Jean's words draw attention to the capitalist modern society where money is the solution to the problems. Jean assumes that as long as he has money, he can buy the social position he inwardly desires. In this regard, title, a social position, can be achieved through money in the materialistic world of Jean as he admits: "Yes, you can buy a title in Rumania" (Strindberg, 1958, p. 96). Thus, he does not appear as a revolutionist character who challenges the system. On the contrary, he desires to be a part of the old system that depends on social hierarchy. Moreover, Jean reveals the fact that how other people perceive him is the most important thing for Jean. Hence, he aims to be approved by others regarding how successfully he can perform characterlessness of his character.

Buying your title versus inheriting it continues to be debated between Jean and Julie. For Jean, upward mobility in the society, beyond a desire, is reflected as an obsession. Julie first rejects the title of countess that will be given to her by Jean upon affording a position and a title for himself. This sets the difference between two characters since Julie is already living the confusion of her place in the society as a result of her mixed background and the 
matriarchal education of her mother. As Jean talks with Julie, on the other hand, he gets even more enthusiastic about his plans and already starts overpowering her using his gender. Outclassing Julie and providing a title for her becomes a subject of their conversation repeatedly in the play. Jean, once again, underlines the power of money to get a title. While Julie reminds him that it is her inheritance, nobility through blood, that makes her a countess, Jean turns to material world promising him a better social position. Jean reflects this to Julie as "Don't you see, I could make you a Countess - you could never make me a Count" (Strindberg, 1958, p. 100). In this regard, Jean challenges Julie and her powerless position within her social class which will reappear in a similar scene in The Hairy Ape as will be discussed. Jean combines his patriarchial superiority with his possible economic prospect to overpower Julie as a female. In this regard, Jean challenges the established traditions by pointing out the changing values of the modern world since he diminishes the power of inheritance.

As the play opens up, the readers and/or the audience meet with Jean in his role as a footman with a scene shared with his fiancée Kristin who is the cook of the house. This can be regarded as an intimate scene that enables two working class characters to share their opinions on Julie while providing some background story on the character for the readers and/or the audience. Yet, as Julie enters the kitchen, Julie's upper class social position struggles to dominate Jean. Jean is depicted as obeying Julie as indicated in the scene when she orders Jean to sit down, to have a beer with her, and to kiss her shoes. Nevertheless, in the play, it is always Jean who reminds Julie of her social class and gender indicating the proper way for her to behave as Lamm touches upon: "[Jean] responds with proper restraint to Julie's advances and warns her again and again not to commit any indiscretion" (1971, p. 113). This marks the fact that in spite of having having class consciousness, Jean, ingeniously, manipulates Julie's social powers based on the superiority of his gender.

With the second half of the play, after the interruption of the singing of the villagers, Jean undertakes the discourse of male authority challenging Julie's upper class social position. The most important fact in this shift of attitude is the implied sexual intercourse between Jean and Julie violating a social order on master-servant relation. From this point, Jean, verbally, shows Julie that he holds the power as a male and shifts the roles in their interaction. In fact, patriarchy becomes the most powerful weapon of Jean who does not hesitate to use against both Julie and Kristin. As Stockenström points out "[i]n Miss Julie the patriarchal order is first and foremost used as the frame for his tragedy [...]" (2004, p. 47). Jean's patriarchial power suppresses his social position and indicates the power struggle between Jean and Julie is about gender as much as about class. The source of Jean's power comes from his position as a male; moreover, the materialistic society that begins to be shaped with capitalism supports his boasting on the possibility of his upward social mobility.

As opposed to Jean's hegemony over Julie, it is only Julie's father, the Count, who can challenge Jean and remind him his real position in the society subverting his desires and dreams. Although he never appears on the stage personally, his authority is constantly reminded to the characters as well as to the readers and/or the audience throughout the play through his boots placed on the stage. As the bell in the kitchen rings towards the end of the play announcing the arrival of the Count to the house, Jean wakes up from his day dream of overpowering Julie and playing the count and returns to his servant identity. As opposed to challenging and obsessed Jean, the arrival of the Count turns him into a submissive working class man as he utters: "I really believe if the Count were to come down here now and order me to cut my throat, I'd do it on the spot" (Strindberg, 1958, p. 118). Regardless of the portrait Jean draws on himself and his power and determination to improve his social class, the end of the play, with the implied arrival of the Count, indicates that Jean in fact has 
internalized his position as a servant in the face of social and economic power of the Count. Regardless of the roles he performs up until that moment in the play, he cannot challenge the real power holder. In this regard, the Count can be pointed out as the representative of the status quo that prevents Jean on his desires. Nevertheless, it can be claimed that through the symbolism of the boots, Jean's trapped position in the class system becomes even more apparent.

\section{The Search of Yank}

Eugene O'Neill's play The Hairy Ape starts out as a realistic play, but, in general, it exemplifies expressionism. The play tells the quest of the brutish Yank in order to find place in the society. Due to journey Yank takes to explore his social position in the play, the structure of the play can be classified as episodic that moves in a fast pace through rapid change of scenes and quick dialogues. While it is appropriate to call the play tragicomic, it also deals with political messages which is mainly a criticism of the capitalist society beneath the personal quest of Yank. Nevertheless, the play is significant for employing sub-standard English, the dialect of the working class, and it is innovative for placing an anti-hero as its protagonist. In this regard, Yank becomes the protagonist of the play while posing mainly as an anti-hero as he rebels to the system. The play not only portrays Yank's journey in a capitalist society, but also the readers and/or the audience also witness the internalization process of his animal like entity. Hence, the journey of Yank ends in a cage of a gorilla as expected. While his unawareness of his reality makes the play comic, tragedy remains the dominant genre of the play. As Berlin discusses " $[\mathrm{t}]$ he audience feels sadness for the man who must go to a gorilla for companionship, who thought he was the center of a circle only to find he is not even on the circumference. When the human muffles the symbolic, the tragic is born" (1982, p. 67). Thus, the story of Yank is also a tragic story whose hero is entrapped by the society as he struggles for his individual identity as Bogard also argues: "[...] The Hairy Ape studies man's attempt to come into harmony with his world, to find to whom, to what he can belong" (1972, p. 242).

When the play opens up, Yank can be observed feeling proud of his physical power which makes him the master of steel. The world below the deck is where Yank belongs according to himself and where he rules the world through his power over steel as he admits in scene one:

I'm de end! I'm de start! I start somep'n and de woild moves! It - dat's me! [...] I'm de ting in coal dat makes it boin; I'm steam and oil for the engines; I'm de ting in noise dat makes yuh hear it; I'm smoke and express trains and steamers and factory whistles; I'm de ting in gold dat makes it money! And I'm what makes iron into steel! (O’Neill, 1959, p. 48)

Within this limited world of Yank, he holds the power. Moreover, it can be claimed that he has a very strong sense of belonging to his place in the system of the ship. Based on the opening scene of the play, Bogard refers to Yank as " $[\mathrm{h}] \mathrm{e}$ is undeniably heroic, perhaps the most conventionally 'heroic' figure O'Neill ever drew" (1972, p. 251). Yet, the world Yank thinks he rules over, in fact, imprisons and oppresses him. As Beard argues, "Yank takes his identity from his place in mechanized society, but this sense of self is a form of oppression imposed on him by his station in life" (2007, p. 62). Eventually, in his quest, Yank aims to secure the lost position within the social and economic system.

Yank's power and pride as a worker are shattered by Mildred who belongs to upper class. She is at the same time the daughter of the president of the Steel Trust which is the name that controls steel in real. Like the opposite setting both characters described in, Mildred on the dock and Yank in the stokehold, they also stand opposing to each other considering the world they belong. Thus, "[t]he contrast is between strength and weakness; while Yank is 
identical with steel, Mildred only possesses steel: the have-nots belong, the haves do not" (Egri, 1984, p. 83). She experiences a sort of identity crisis, a question of belonging, between the current position of her father and the working class past of her grandfather. Nevertheless, Mildred can be perceived symbolizing both the power of the upper class, money in the capitalist system, and the sensitivity of her gender. In this regard, Yank interprets Mildred's actions judging Yank based on his appearance. Thus, Yank feels as if his assumed power is challenged by Mildred. This leads Yank to an awakening, to a quest that results in a loss of belonging and identity.

The last four scenes of the play depict the internal journey of Yank as he gradually turns into the "filthy beast" that Mildred referred to. Yank solidifies his outsider position in the capitalist society he lives in which is fueled by his personal revenge for Mildred . Through his quest, his obsession to belong is depicted. Both his vain intention of revenge and his alienation from the society and from the identity he assumes are mostly apparent in scene seven where Yank goes to join to the branch of the Industrial Workers of the World which he hears in the prison. In the union, which is supposed to be a political ground for Yank and working class to raise their voice and have a political impact, he is refused by the other workers due to his violent ways of protest. This is also the scene where Yank's formal name is revealed. Representing the lack of individual identity and the sense of belonging, by then he is only known as Yank. Through his dialogue with the secretary of the union, it is revealed that his formal name is Robert Smith which is a very common English name. Through this name, Ruby Cohn refers to Yank as "an American Everyman" (1971, p. 17). In this regard, even his full name refers to his ordinary position in the society as opposed the power Yank associates with himself. It is also ironic that Yank's alienation from the society gets even more severe after his formal name is revealed. Hence, realizing his own personal name and surname does not guarantee an identity to Yank as opposed to the function of having a unique identity and sense of belonging.

When the play ends in the cage of gorilla, the alienation of Yank is concluded. He returns to the place the society assumed him to belong to. As opposed to Yank's struggle and quest to be a human and have a social position, the readers and/or the audience witness degradation of Yank by the society. After being symbolically caged, first within stokehold, later among the society in the $5^{\text {th }}$ Avenue and in the prison, finally Yank is forced to get into an actual cage as a result of being rejected by the social system. Eventually, Yank internalizes impositions of the society dispelling his desires to be a human and useful to the society. Through this journey, the society constitutes the status quo that prevents Yank from finding his own identity and place in the society. Rather, the society and the capitalist system force Yank to take refuge in the cage of the gorilla out of Yank's despair.

In this regard, Jean Chothia derives such message from the play: "In this play, that experience is concerned with human alienation in the complex industrial society; the search for personal significance in a world that has lost faith in metaphysical purpose" (1989, p. 35). According to Brugnoli, "[i]n The Hairy Ape, too, O'Neill presents his audience with a scenario of isolation in which interactions, situations, and social practices are all about building up walls rather than bridges" (2012, p. 53). For Berlin, on the other hand, the play expresses that "[m]an's desire to belong, his quest for belonging, is the measure of his humanity, even though he fails to belong" $(1982$, p. 68). As these critics point out, the play is a story of an individual who suffers at the hands of the society. As a victim of the society, Yank reaches to the acceptance of his ape like nature as dictated by the capitalist society which forces him to cage himself and alienate him from the society to make sure that he is aware of his position within that society. 


\section{From Jean to Yank}

Two plays, as discussed separately, are written thirty-four years apart from each other in different cultural and social contexts. Yet, the male characters of the two plays, Jean and Yank, share a similar quest for their position in the society. In this regard, both characters experience a similar confrontation, internalization, and struggle within the plot structures. To begin with, the confrontation of the characters, Yank with Mildred and Jean with Julie, enables both the recognition of the differences in terms of their class and the starting point of their quest for a better place in the society. Such recognition can be observed more clearly in The Hairy Ape. As Mildred comes down to the stokehold, she takes up a challenge that as a member of the upper class she can also endure the conditions of the working class. This act triggers the actions of Yank making him realize his working class environment leading him to take revenge from the upper class. It is also quite significant that such confrontation between characters belonging to different social classes takes place in the stokehold which is the world Mildred does not belong although she claims that her grandfather came from that world. A similar scene in a similar background also takes place in Miss Julie. Through the discussion of the social titles, Julie challenges Jean's bought title while revealing that she cannot be degraded to his position although he can buy and provide a title for her. Just like the setting of The Hairy Ape as discussed, the confrontation on their social position as by birth or by money takes place in the kitchen of the house as a place where Julie does not belong. Yet, different than the interaction between Yank and Mildred, Jean takes advantage of his gender to overpower Julie. Eventually, Jean deceives Julie with a dream of power of money. Nevertheless, in both plays the questioning of both male characters is triggered by female characters. Thus, the power struggle of Jean and Yank and the questioning of their social position intermingle with their gender. In this regard, both plays, at the same time, lays out the complicated relation among patriarch, aristocracy and capitalism.

The two characters also share internalization of their status, Jean as a servant and Yank as a "filthy beast." While both plays highlight their struggle to escape from their assumed social positions, they end up unconsciously acknowledging their positions. In both plays, this is mainly highlighted with the ending of the plays. In Miss Julie, regardless of Jean's rhetoric throughout the play and his overpowering Julie through his gender, Jean eventually yields to the Count. As the supreme power of the play, the Count reminds Jean of his position as a servant. Again, regardless of his acting against the reality, just the sound of the bell orients Jean to go back to his servant position. The authority of the Count makes Jean internalize his status. The inevitable end of Yank also drives from his internalization of his position and his characteristic as brutal and filthy. While internalization of Jean's social status, in Miss Julie, is mostly highlighted at the end of the play with the arrival of the Count, it is treated as a process in The Hairy Ape. The readers and/or the audience witness internalization of Yank's description as a brutal, filthy, and insignificant person starting from his encounter with Mildred until his death in the gorilla's cage. Nevertheless, it is accepting the words and perspective of Mildred, and considering himself as the target that leads Yank to such a tragic end. On the other hand, in both plays, both Julie's father, the Count and Mildred's father, the president of the Nazareth Steel play a similar role in terms of establishing power. Compared to the boots of the Count, the steel in The Hairy Ape stands for the power of the president. Through symbols, their power within the social and economic system is constantly reminded to the male characters. While boots remain on the stage as a warning to Jean, Yang brags about his supposed control over the steel although it belongs to someone stronger than Yang. In this regard, from the very beginning of the both plays, it is indicated that neither Jean nor Yang can defeat the system and achieve their goals. 
In both plays, Jean and Yank are portrayed as they strive to become a part of the society that rejects them rather than acting revolutionarily against it. As discussed previously, Jean aims to move upward in the society with the power of money. In a system that uses and oppresses him, rather than reacting, Jean desires to be a part of the system so that he can take revenge by oppressing others. His struggle to be a part of the system is prevented by the status quo, the old system of aristocracy as the real power holders represented by the Count. Yank also goes through a similar experience which also entitles his journey as his struggle to be a part of the system. Although he nests the idea of blowing up to take his revenge, he inwardly wishes to be a part of the system and to be accepted by a certain group of people whether by his fellow workers or by the union. It is only after realizing the fact that he fails in his struggle to be accepted by the system that he takes refuge at the gorilla's cage at the zoo. Yank and his place in the society are also denied by the status quo. It is primarily the capitalist system, as pointed out previously, which rejects Yank's existence in the system as first represented by Mildred and later by the $5^{\text {th }}$ Avenue in New York and the union. In this regard, both characters first struggle to be able to be a part of the society and then suffer from the society and the status quo.

\section{Conclusion}

Strindberg's Miss Julie and Eugene O'Neill's The Hairy Ape differ from each other when their technicality is considered although Strindberg is a pioneer name and an inspiration for O'Neill. Written in two different centuries, in two different cultural backgrounds, and in two different theatrical movements, both plays stand quite significant on their own terms as briefly touched upon. Nevertheless, consideration of these two plays thematically also reveals similarities between each other. In this respect, the male characters of the plays, Jean and Yank, experience a similar process on fighting against the society to determine their social positions. Rather than struggling for the idea of betterment of the society for their classes, both Jean and Yank suffer individually. In conclusion, Strindberg and O'Neill, in these two plays, portray two male characters who are defeated by the society on establishing their individual identities. They fight against the society, Jean against the old aristocracy and Yank against the capitalist system. Yet, both of them fail to be a part of the system being a victim of their internalization of their lower class positions. Yet, being victims of their internalization of their lower class positions, both of them fail to be a part of the system.

\section{References}

Beard, D. M. T. (2007). A Companion to Twentieth-Century American Drama. David. Krasner (Ed.) "American Experimentalism, American Expressionism, and Early O’Neill” (pn. 51-68). Oxford: Blackwell.

Berlin, N. (1982). Eugene O’Neill. London: MacMillan.

Bogard, T. (1972). Contour in Time. New York: Oxford UP.

Brugnoli, A. (2012). "Eulogy of the Ape: Paradigms of Alterity and Identity in Eugene O'Neill's The Hairy Ape." Eugene O'Neill Review, 33 (1), 43-55.

Chothia, J. (1989) Eugene O'Neill and The Emergence of American Drama. Marc Maufort (Ed.) "Theatre Language: Word and Image in The Hairy Ape" (pn. 31-40). Amsterdam: Rodopi.

Cohn, R. (1971). Dialogue in American Drama. Bloomington: Indiana UP.

Egri, P. (1984) Critical Essays on Eugene O'Neill. James J. Martine (Ed.) “'Belonging' Lost: Alienation and Dramatic Form in Eugene O'Neill's The Hairy Ape” (pn. 77-111). Boston, Massachusetts: G. K. Hall.

El Sanhoury, N. A. R. (1982) O'Neill and Intellectual Influences. (Unpublished Dissertation). State University of New York at Buffalo.

Hartman, M. (1966). "Strindberg and O'Neill.” Educational Theatre Journal. 18(3), 216-233. 
Lamm, M. (1971). Strindberg: A Collection of Critical Essays. Otto Reinert (Ed.) "Miss Julie" (pn. 105-116). Englewood Cliffs, New Jersey: Prentice-Hall.

Meyer, M. (1986). File on Strindberg. London: Methuen.

O’Neill, E. (1959). The Hairy Ape. New York: The Modern Library.

Shideler, R. (2009). The Cambridge Companion to August Strindberg. Michael Robinson (Ed.) "Miss Julie: naturalism, 'The Battle of the Brains' and sexual desire" (pn 58-69). Cambridge: Cambridge UP.

Stockenström, G. (2004) "The Dilemma of Naturalistic Tragedy: Strindberg's Miss Julie." Comparative Drama. 38:1, 39-57.

Strindberg, A. (1958). Miss Julie. London: Penguin.

Templeton, A. (1990). "'Miss Julie' as 'A Naturalistic Tragedy'." Theatre Journal. 42(4), 468-480.

Törnqvist, E. and Jacobs B. (1988). Strindberg's Miss Julie: A Play and Its Transportations. Norwich: Norvik Press. 